\title{
Environmentally Friendly Foundry Molding and Core Sands
}

\author{
K. Major-Gabryś \\ (Submitted September 28, 2018; in revised form January 23, 2019; published online February 21, 2019)
}

\begin{abstract}
The paper describes the current state of knowledge in a field where change has been driven in foundry molding sand practice due to the increasing requirements regarding environmental protection. These trends must take into account not only the technological quality and economics of their production process, but also the increasingly stringent requirements related to environmental protection. As part of this study, tests were performed in relation to reducing the toxicity of current molding sands with organic binders, so as to develop new organic binders for foundry practice. Molding sands with binders having various contents of furfuryl alcohol were tested. It was shown that reducing the total furfuryl alcohol content in the binder results in lower strength properties of the molding sands in practice. It was also suggested to replace the use of a furfuryl binder with one based on alkyd resin. The final stage of the study was to demonstrate the desirability of using biomaterials as a component of organic binders for foundry molding sands. Compositions: typical synthetic resins and biodegradable materials were designed as binders to improve the quality of the organic binders used with molding sands.
\end{abstract}

Keywords foundry engineering, green industry, molding and core sands, organic binder, biomaterial

\section{Introduction}

The contemporary economic situation requires the manufacture of products that meet the highest quality criteria. Such products include castings used in the automotive, construction, metallurgical and cement industries, as well as those for the art and jewelry industry. In the context of the Polish economy, the production of castings is significant. One of the basic factors affecting the quality of the finished castings, mainly in terms of dimensional accuracy and surface finish, is the quality of the molds and foundry cores. These in turn depend on the type and quality of the molding and core sands.

Due to the variety of foundry alloys, casting technologies, and both mass and quality requirements, it is necessary to use a number of different molding and core sands. In terms of size, the greater the mass of the casting, the greater the effect of the casting alloy on the molding or core sand. The type of casting and its pour temperature affect the selection of a suitable molding sand, due to the potential for chemical reactions at the alloy-mold interface. Additionally, the quality class required

This article is an invited submission to JMEP selected from presentations at the 73rd World Foundry Congress and has been expanded from the original presentation. 73WFC was held in Krakow, Poland, September 23-27, 2018, and was organized by the World Foundry Organization and Polish Foundrymen's Association.

K. Major-Gabryś, Department of Molding Materials, Mold Technology and Foundry of Non-ferrous Metals, Faculty of Foundry Engineering, AGH University of Science and Technology, Reymonta 23, 30-059 Kraków, Poland. Contact e-mail: katmg@agh.edu.pl.

for the casting by the recipient also affects the selection of an appropriate molding and core sand.

The trends in modern foundry engineering regarding molding sands and mold technology result from three main requirements: ensuring the appropriate technological properties of the mold and core, the economic efficiency of the process, and low levels of harm to the environment (Ref 1,2).

Ensuring adequate technological properties for the mold and core, and high economic efficiency, are all very important factors in the development of molding sands. The high economic efficiency of the process relates to its total efficiency, including the speed of creating the molds and cores (speed of molding sand binding process), material prices, manufacturing costs, cast knocking-out, finishing and cleaning costs, as well as the employment costs for all employees, including qualified staff. However, in recent years, a dominant factor in the development of molding and core sand technologies has been the need to comply with high environmental protection requirements $(\operatorname{Ref} 1,2)$. A new instrument in the protection of the environment as a whole is the introduction of integrated permits. These cover a variety of emissions to the environment: dust, gas, energy, electromagnetic fields, noise, heat, sewage and waste, as well as savings in terms of resources and materials. Integrated permits were introduced into the European Union legislation by the IPPC Directive of 1996 (Ref 3).

The development of regulations related to environmental protection in the countries of the European Union illustrates well the number of new legal provisions in this area and the dynamics of their formation (Ref 4). The data show that the years 1865-1970 saw 20 new acts related to environmental protection being introduced, the years 1971-1985 saw 94 new acts, and the years 1986-2014 saw a further 800 new acts (Ref 4).

The trends related to the need to comply with high environmental protection requirements are intensifying to such an extent that even technologies for production processes that have worked well for decades must be replaced with more 
ecological solutions. Some examples of these activities are presented below.

\section{Molding Sand with Bentonite and Coal Dust}

The first example of implemented activities connected to environmental protection requirements is molding sand with bentonite and coal dust (green sand). While the molding sands with bentonite, used to make molds for steel casts or aluminum alloys, are considered ecological, the addition of lustrous carbon carriers, for example, coal dust or synthetic resins, makes the molding mixture very harmful to the natural environment. It also creates harmful working conditions (Ref 5). In 1995 in Poland, the maximum permissible concentration ('NDS') value for the benzo(a)pyrene emitted was determined at the level of $0.002 \mathrm{mg} / \mathrm{m}^{3}$ (Ref 6). The tests have shown that among the various molding and core sands (including molding sands with organic binders) mixtures with bentonite and coal dust are characterized by the highest quantity of benzo(a)pyrene (belonging to PAHs) emitted during pouring. The results of the tests are presented in Fig. 1 (Ref 7, 8).

After pouring liquid metal into the molds, the applied organic additives in molding sand undergo high-temperature pyrolysis, leading to the formation of lustrous carbon (necessary to achieve good surface quality of the castings). This process is always accompanied by the formation of volatile organic compounds and polycyclic aromatic hydrocarbons (PAHs) - including benzo(a)pyrene - and benzol hydrocarbons (BTEX), which have not participated in the reactions of thermal polycondensation and polymerization. They are particularly harmful due to their carcinogenic, mutagenic and teratogenic properties (Ref 7).

Nowadays various technologies are used to limit the emission of harmful substances into the environment from molding sands with bentonite, such as coal dust substitutes or the introduction to molding sand substances that largely neutralize the harmful compounds (Ref 1,9$)$.
Flammable protective coatings are another good example of environmentally friendly improvements. Protective coatings have been used in foundry engineering for a long time, typically based on organic solvents, mainly isopropyl alcohol. The European Union requirements, however, require the elimination of the use of organic solvents in the industry. This requires coating manufacturers to develop solutions based on water-based solvents, i.e., water soluble coatings with a low water content that do not require drying in heating chambers (Ref 10).

\section{Molding Sand with Ethyl Silicate for Precision Foundries}

Another example of implemented activities connected to environmental protection requirements is molding sand with ethyl silicate.

Since April 1997, regulations regarding environmental protection have been introduced in European Union. These regulations caused the necessity of eliminating or reducing all volatile organic components which could escape to the atmosphere to a given level of emission, introducing a ban on, among others, use of ethyl or isopropyl alcohol in precision foundries. Due to the process of hydrolyzing the ethyl silicate used to prepare molding sands with the use of organic solvents, it became necessary to seek new environmentally friendly binders for precision casting. The result of this research was the implementation of molding sands using colloidal silica (Ref 11).

The basic technological parameters in the process of making the ceramic mold, which later mainly affect the quality of the cast, are: accurate representation of the shape of the model, strength properties of the ceramic mold and its permeability (Ref 12).

The first step was to develop a technology for the production of silica sol-Sizol 030 . Next, a method to alternate layers of the ceramic mold with the participation of hydrolyzed ethyl silicate 40 and Sizol 030 (patent No. 116 013) was developed (Ref 11).

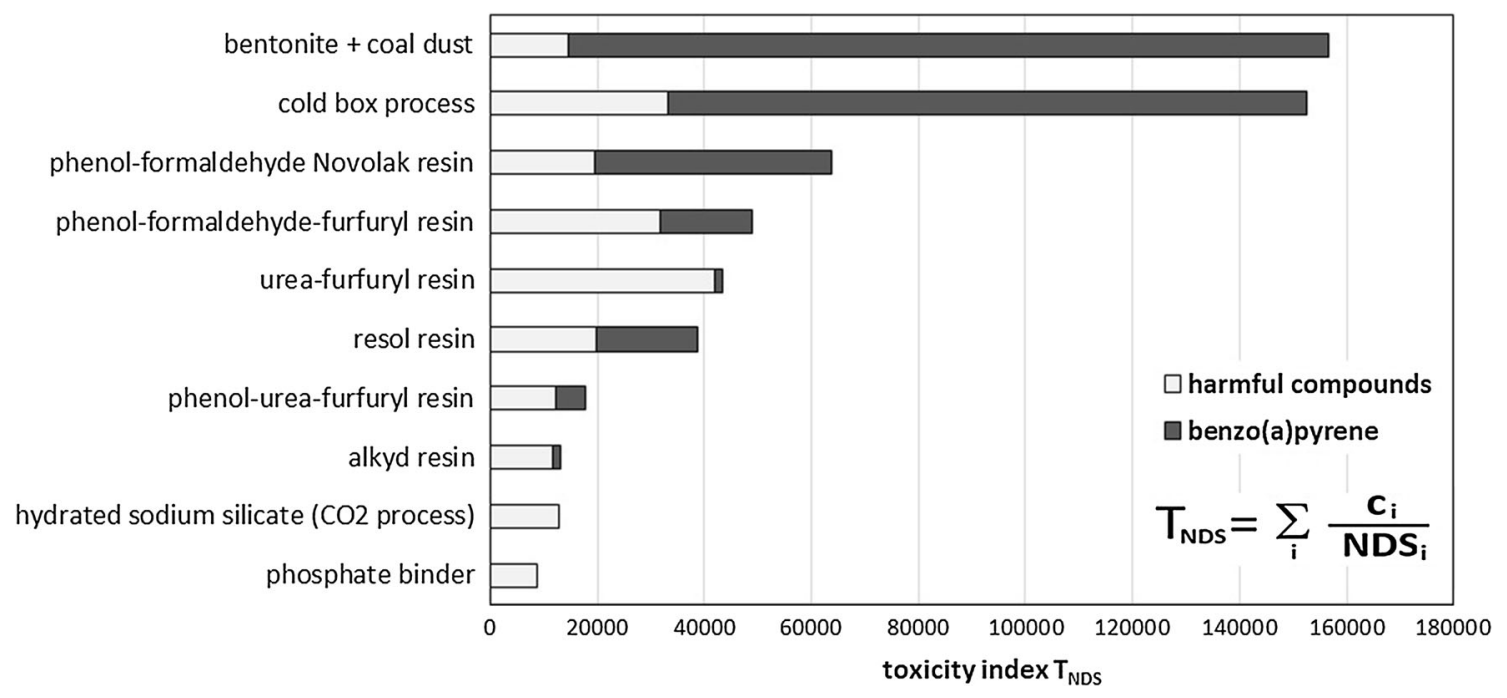

Fig. 1 The share of benzo (a) pyrene in the total harmfulness (measured by toxicity index $T_{\mathrm{NDS}}$, where $c_{i}$ is concentration of $i$-th harmful substance formed during the decomposition of $1 \mathrm{~g}$ of mass, in $\mathrm{mg} / \mathrm{m}^{3}$ and $\mathrm{NDS}_{\mathrm{i}}$ is maximum permissible concentration of $i$-th harmful substance, in $\mathrm{mg} / \mathrm{m}^{3}$ ) of molding and core sand with various binding materials (Ref 7,8 ) 


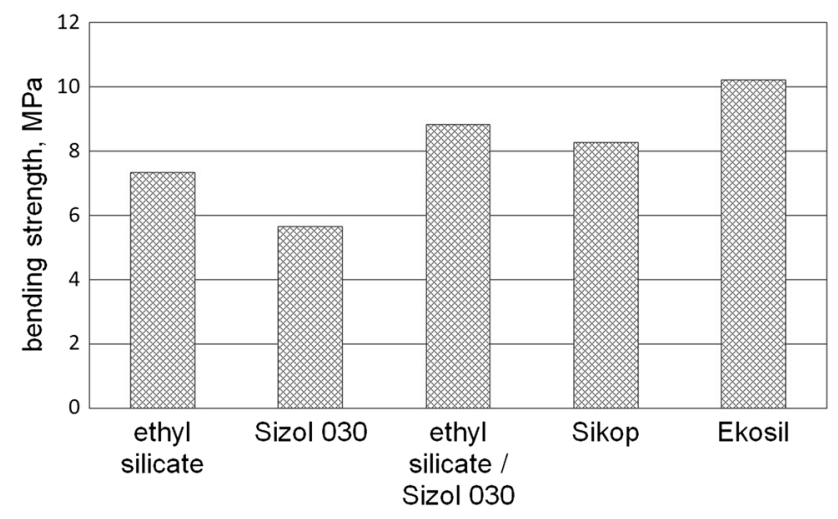

Fig. 2 Bending strength of ceramic molds with different binders (Ref 12, 13)

The next step was the development of Sikop copolymer silicate binder (patent No. 135 579), which allowed to reduce the consumption of ethyl silicate and organic solvents by about $30 \%$ in relation to the alternating layers technology: hydrolyzed ethyl silicate and Sizol 030 (Ref 11). Finally, in the 1990s, the Ekosil binder was elaborated (patent application No. P319315) — an 'aqueous' silicate inorganic binder with a minimum content of ethyl silicate and organic solvents (Ref 11).

The presented test results show that the mixture with Ekosil binder is characterized by better strength properties than the mixtures with previous binders (Fig. 2). The authors (Ref 11, 12) also showed that the use of Ekosil 'aqueous' silicate binder instead of an ethyl silicate-based binder provided a more accurate mapping of the model's shape by the ceramic mold made with it. Permeability of the ceramic mold was also better (Ref 11, 12). It should be emphasized that the change of ethyl silicate in the Ekosil binder will improve working conditions in the foundry by eliminating toxic ethyl silicate and ethyl alcohol.

\section{Molding Sand Prepared in Cold-Box Technol- ogy}

The last example is cold-box technology and the solvents based on PAHs used in it.

The cold-box process is a perfect example of how environmental protection requirements have influenced technological development. Over the years, the classic cold-box process has changed very significantly in terms of pro-ecological aspects. As a result of the changes, 5 generations of the process have been created: generation 1-based on aromatic solvents, generation 2 and 3-based on aliphatic solvents and generations 4 and 5 , in which the organic solvents were replaced with ecological solvents, where carbon atoms are replaced with silicon atoms (Ref 14). The change in the percentage of carbon and silica in generations of the cold-box process with total BTX level of core sands is shown in Fig. 3 (Ref 4, 15).

However, it should be emphasized, however, that this change resulted in a reduction in the core sands strength properties from $5.48 \mathrm{MPa}$ achieved for mixtures based on aromatic solvents (generation 1) (Ref 16) to 3.6-3.2 $\mathrm{MPa}$ (depending on the amine blowing pressure) achieved for mixtures based on mineral solvents (generation 4) (Ref 17).

\section{Self-Hardening Molding Sand with Organic Binders}

From the point of view of technological properties, the greatest application in foundry practice involves molding sands using organic binders (synthetic resins).

There have been significant changes recently in the structure of the European foundry industry, such as the rapid development of the production of cast iron with dense graphite, as well as light alloys, at the expense of limiting the production of cast steel. This has created a significant gap in the production of heavy cast steel (castings exceeding $30 \mathrm{Mg}$ ) for the metallurgical, cement and energy industries. The problem is the mold technology for such heavy castings, as their clotting and cooling time can last up to several days, which exposes the molding material to long-term thermal and mechanical loads.

For the production of cast steel, foundries typically use molding sands bonded with synthetic resins. The manufacture of this type of casting has been dominated by self-hardening molding sands using furfuryl resin.

On 1 December 2010 the Regulation of the European Parliament and of the Council (EC) (No. 1272/2008 of 16 December 2008 on the classification, labeling and packaging of substances and mixtures) came into force, which classified furfuryl resins containing more than $25 \%$ of free furfuryl alcohol as toxic. Furfuryl resins, which contain a lower level of free furfuryl alcohol, were regarded as harmful (Ref 1, 18).

According to the tendencies described above, the molding sands chosen for this study were self-hardening with organic binders belonging to the group of universal applications (used as mold and core compounds), such as furfuryl and alkyd resin molding sands.

All of the tested molding sands were prepared in accordance with the recommendations of the manufacturers of the given binders (Ref 19, 20), in a $6 \mathrm{~kg}$ capacity Vogel and Schenmann laboratory mixer. The hydrothermal conditions under which the mixtures were prepared and the fittings stored ranged between 22 and $28{ }^{\circ} \mathrm{C}$ and $30-34 \%$ humidity.

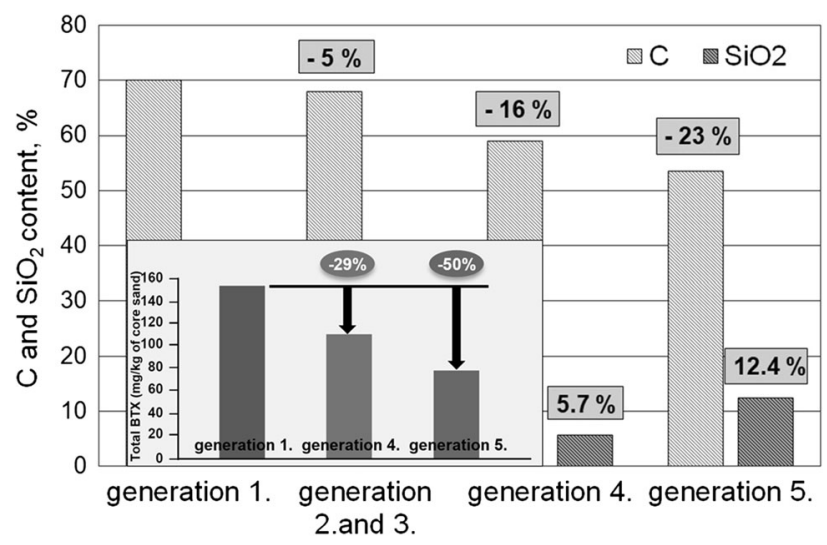

Fig. 3 The change in the percentage of carbon and silica in generations of the cold-box process with total BTX level of core sands $(\operatorname{Ref} 4,15)$ 
Figure 4, 5 and 6 shows the results of the bending strength tests of selected self-hardening molding sands. Molding sands with furfuryl resin with different furfuryl alcohol contents (1, 75 and $90 \%$ furfuryl alcohol), molding sands with alkyd resin and molding sands with two-component binder were all taken into consideration.

The study demonstrated that it was possible to use a more environmentally friendly furfuryl resin with a reduced content of free furfuryl alcohol. However, this resulted in a significant reduction in the strength properties of the molding sands, down from approx. 4.6 $\mathrm{MPa}$ (FR90) to $2.1 \mathrm{MPa}$ (1\% of furfuryl

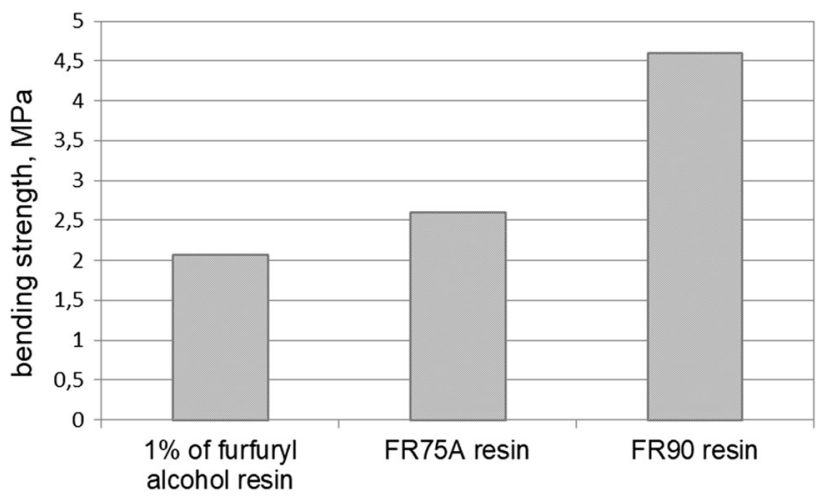

Fig. 4 Bending strength of molding sands with different contents of furfuryl alcohol (Ref 1)

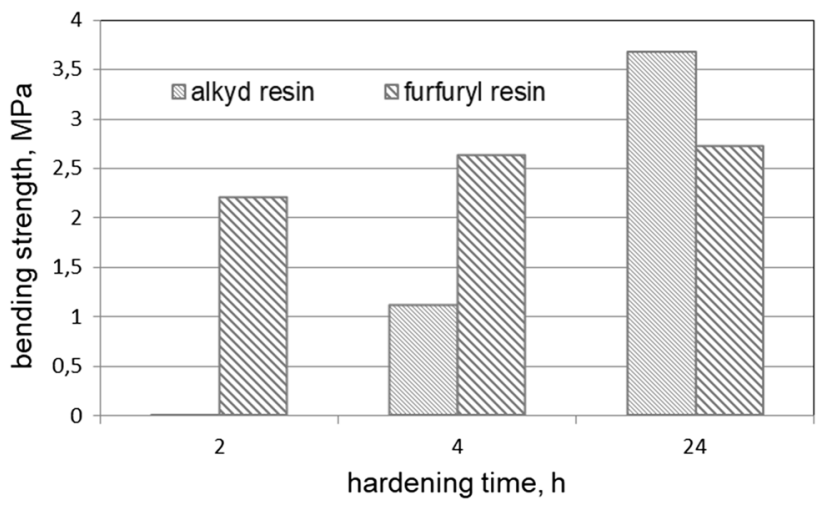

Fig. 5 Bending strength results for molding sands with furfuryl and alkyd resin (Ref 1)

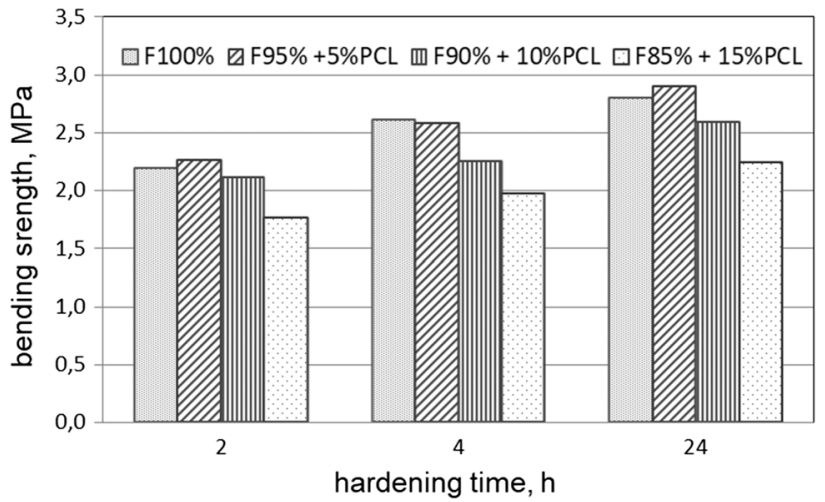

Fig. 6 Bending strength results for molding sands with twocomponent binders (Ref 21) alcohol resin). It should be noted that for many applications a lower strength of molding sand may still be sufficient.

It is also possible to replace the furfuryl resin molding sands with more ecological alkyd resin molding sands. However, the latter feature a reduced curing rate, which can be either a disadvantage or an advantage, depending on the production profile of the plant.

Molding sands based on a new two-component binder have been developed by the author, and selected results are presented in this publication.

\subsection{Two-Component Binders: Furfuryl Resin and Biodegradable PCL}

The new direction taken in the author's research is to prepare a new binder containing typically used resin and biodegradable material. Furfuryl resin and biodegradable PCL were both tested in this study. The following materials were selected as components for the new binders:

- Phenol-furfuryl resin as a binder and an aqueous solution of paratoluenesulfonic acid as a hardener. The furan resin did not contain nitrogen, and the free formaldehyde content was in the range of $0.05-0.15 \%$. The amount of furfuryl alcohol was $78 \%$.

- Polycaprolactone (PCL) in powdered form was used as a biodegradable additive and plasticizer. It is a biodegradable polymer with an end hydroxyl group.

The selection of these materials was primarily based on the fact that PCL could be dissolved in the resin, so there was no need for an additional solvent to dissolve the biodegradable polymer (Ref 21, 22). Quartz sand was used to prepare the molding sands with the two-component binder. According to Polish standard $\mathrm{PN}-85 / \mathrm{H}-11001$, the tested sand was classified as medium. In the matrix, the value of the main fraction was $84 \%$, which meant the sand was homogeneous.

The first step was to test the viscosity of the new binders. Figure 7 shows the flow curves determined for the binders.

The flow curves had a linear character, where the shear stress $\tau$ (shear) was proportional to the shear rate $\gamma$ described by the Newtonian Eq 1.

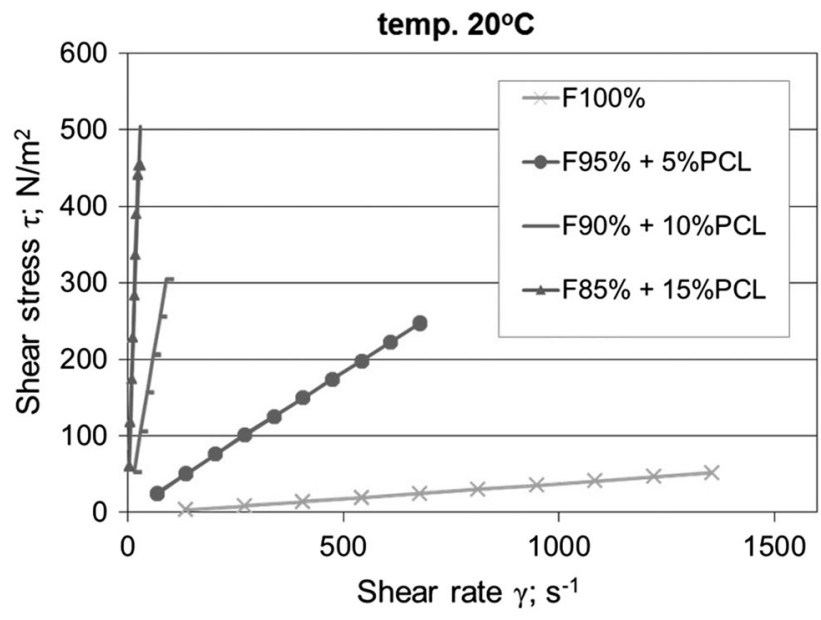

Fig. 7 Flow curves (relationships of shear stress $\tau$ as a function of shear rate $\gamma$ ) determined for binders with various contents of furfuryl-based resin and PCL (Ref 21) 
$\tau=\eta \cdot \gamma[\mathrm{Pa} \cdot \mathrm{s}]$

The viscosity of the fluid under simple shear conditions was described by $\eta(\operatorname{Ref} 23)$.

On the basis of the obtained relations of shear stress $\tau$ as a function of the shear rate $\gamma$, the values of the viscosity parameter $\eta$ were determined (Fig. 8).

Figure 8 shows that as the PCL content in the binder increases, its viscosity increases as well. Correspondingly to the initial binder, a F100\% pure furfuryl resin with a viscosity of $0.039 \mu$, a binder with the addition of $5 \%$ PCL achieved a viscosity almost ten times higher, at $0.362 \mu$. A similar trend could be seen by comparing the F95\% $+5 \%$ PCL binder with $\mathrm{F} 90 \%+10 \% \mathrm{PCL}$, which gave an increase from 0.362 to $3.362 \mu$. The last of the tested mixtures showed the highest viscosity, at $17.88 \mu$. The tests showed an increase in viscosity of the binder, along with an increase in the share of biodegradable material in its composition. The increased viscosity of the binder could affect the need to prolong molding sand mixing operations in order to achieve the required coating of the sand grains with the binder material. In the case of self-hardening molding sands, which are characterized by a short working time, this could be a complication (Ref 21).

The next stage was spectroscopic studies (FTIR) of the new binders. The aim of these studies was to determine the effect of the biodegradable material on the structure of the new twocomponent binder. Structural analyses were carried out using an Excalibur FTIR spectrometer with a standard DTGS detector and a resolution of $4 \mathrm{~cm}^{-1}$. The spectra of the samples were obtained at room temperature using the transmission technique (KBr pellet). A small amount of liquid binder was smeared onto a $\mathrm{KBr}$ pellet (prepared by pressing $\mathrm{KBr}$ powder under a load of $8 \cdot 103 \mathrm{~kg}$ ). The number of scans was constant for all samples. The results were registered for wave numbers from 4000 to $400 \mathrm{~cm}^{-1}$ at a resolution of $4 \mathrm{~cm}^{-1}$ (Ref 24). See Fig. 9.

The addition of $5-15 \%$ of PCL to the furan resin (Fig. 9) resulted in the appearance of a band at the $1105 \mathrm{~cm}^{-1}$ wavenumber, derived from the vibration of the $\mathrm{CH}_{2}$ in PCL. There was also a growth in intensity for the band at the $1730 \mathrm{~cm}^{-1}$ wavenumber, caused by the vibration of extending the carbonyl bond $\mathrm{C}=\mathrm{O}$ with the increasing addition of PCL (Ref 24). Other bands in the resin spectrum did not change with increases in PCL amount (Fig. 9). It is possible that PCL

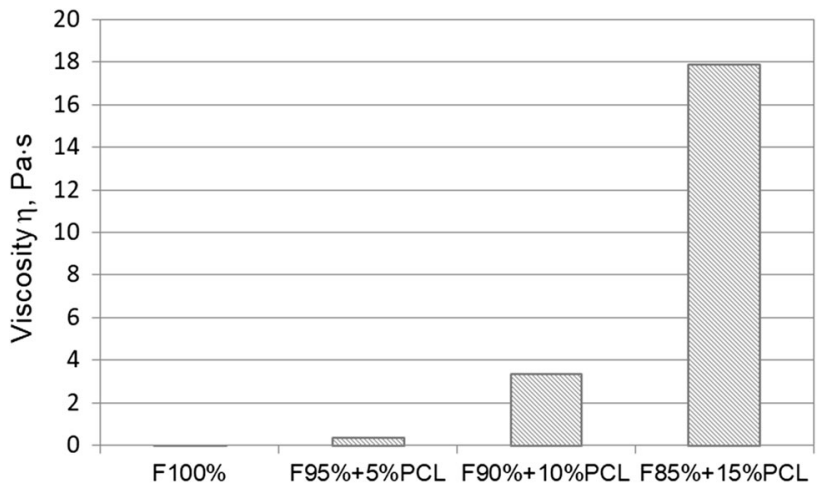

Fig. 8 Viscosity determined for binders with various contents of furfuryl-based resin and PCL (Ref 21) entered the phenol-furfuryl resin structure, although this was not possible to prove within the current study (Ref 24).

An additional advantage of using a PCL polymer as a biodegradable additive is the increase in the flexibility of foundry molding sands. The use of PCL as a plasticizer for plastics is not new. Polycaprolactone has been used as a plasticizer in mixtures with aliphatic polyesters, cellulose esters, aromatic polyesters, polycarbonates, styrene-containing polymers (e.g., polystyrene), polyolefins, block copolymers, and Novolak resin (Ref 1, 25).

Cores and molds are subject to a variety of mechanical and thermal factors at each stage of their manufacture and use. There are various technological operations which involve many possible sources of damage to the molds and cores. Such operations include: removal of cores from core boxes, removal of patterns from molds, core and mold assembly, applying weights to molds, etc. In highly mechanized foundries such operations, often performed by manipulators, can generate cracks in the cores and molds which may later lead to defects in the castings. This is due to the high brittleness of cores and molds, so one of the aims of modern technology is to develop molding mixtures having relatively high levels of elasticity (Ref 26, 27).

Measuring the resistance of a molding sand to mechanical deformation is achieved using a universal apparatus for studying hot-distortion phenomena and bending strength, as available from Multiserw-Morek (Ref 28). The methodology has been described in detail in previous publications (Ref 1, 28, 29).

The next stage of the study involved mechanical deformation tests of chosen molding sands with two-component binders. The tests were carried out according to the methodology mentioned above. Figure 10 shows the results obtained for molding sands with two-component binders.

The studies showed that those mixtures with PCL added to the binder were more elastic than the analogous additive-free molding sands. The elasticity of a sample without the additive was $0.25 \mathrm{~mm}$ under a load of about $150 \mathrm{~N}$ (F100\% molding sand), whereas the introduction of $5 \%$ PCL resulted in an increase in the molding sand deformation of up to $0.28 \mathrm{~mm}$. Replacing $5 \%$ of the binder with PCL (F95\% + 5\% PCL) increased the deformation of the molding sand to approxi-

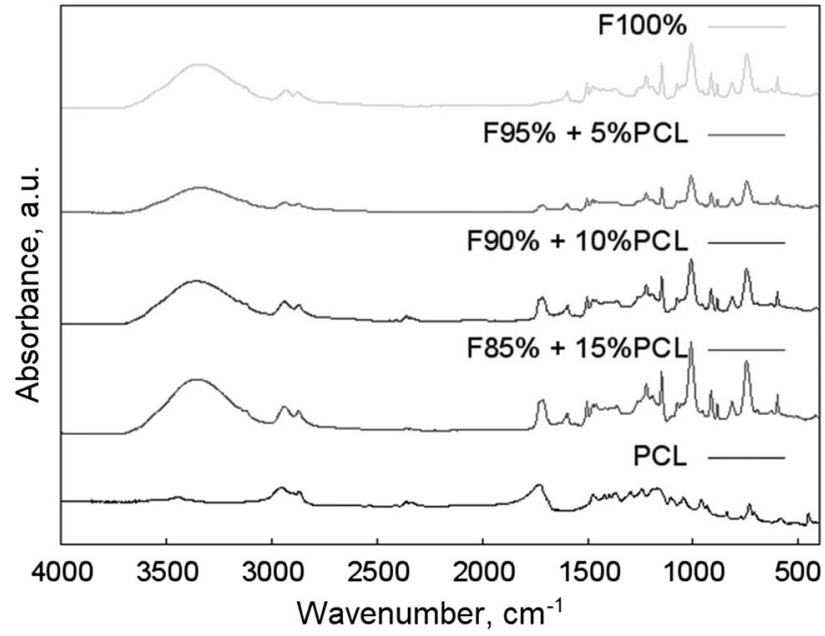

Fig. 9 FTIR curves for binders with various contents of furfurylbased resin and PCL (Ref 24) 


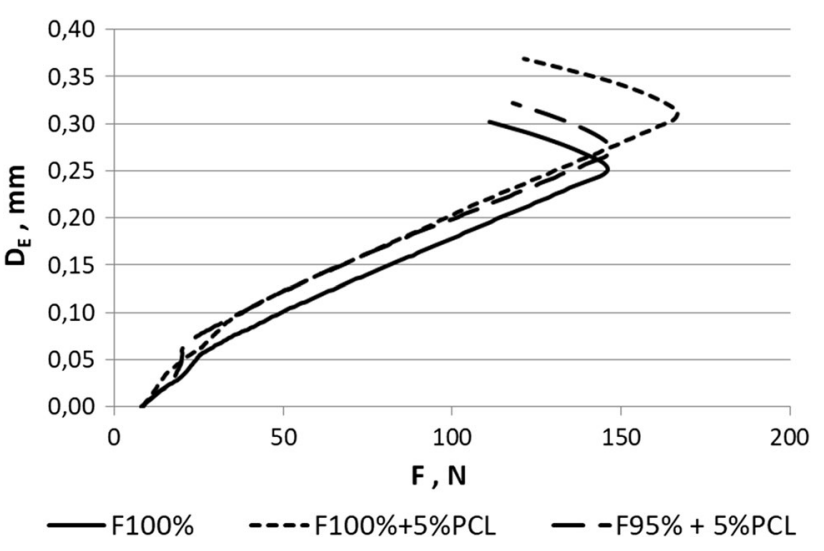

Fig. 10 Mechanical deformation of molding sands with a twocomponent binder (Ref 30)

mately $0.32 \mathrm{~mm}$, under a load around $150 \mathrm{~N}$ (a nearly $30 \%$ increase in comparison with the additive-free molding sand) (Ref 30).

\section{Conclusions}

A combination of literature analysis and the study results proved that in recent years a dominant factor in the development of molding and core sand technologies has been the need to comply with high environmental protection requirements. In green sands with bentonite, it is necessary to use various technologies to limit the emission of harmful substances into the environment. Those technologies include coal dust substitutes or the introduction to molding sand substances that largely neutralize the harmful compounds in molding sands. In molding sand using ethyl silicate, it became necessary to seek new environmentally friendly binders for precision casting. The result of this research was the implementation of molding sands using colloidal silica. In cold-box process, as a result of proecological changes, five generations of the process have been created. In generation 4 and generation 5 , the organic solvents were replaced with ecological solvents, where carbon atoms are replaced with silicon atoms. The core sands' toxicity is lower, but their strength is decreased.

The results of the analysis show there is a need to develop new systems for bonding molding and core compounds that guarantee low harm to the environment and at the same time meet high technological requirements. In the paper, author focused on self-hardening molding sands with furfuryl resin. Lowering the content of furfuryl alcohol in the binder, application of alkyd resin and replacement of a part of the furfuryl resin with biodegradable material has been proposed as one of pro-ecological solutions. It was proved that lowering the content of furfuryl alcohol in the binder also lowers the strength of the molding sand. This property can be difficulty, but not necessarily, since the strength of the molding sand is sufficient from a practical point of view. As an alternative to molding sands with furfuryl resin, mixtures with an alkyd binder were proposed. The strength tests of the self-hardening molding sands show that molding sands with an alkyd binder are characterized by noticeably slower hardening process than molding sands with a furfuryl binder, which means that the working time of the molding sand with an alkyd binder is longer. This molding sand property may be beneficial or unfavorable depending on the plant's production profile. Studies have shown that it is possible to replace a part of the furfuryl resin with biodegradable material. The $5 \%$ addition of PCL to a molding sand using furfuryl resin does not affect the molding sand strength properties but does improve its elasticity. Research using biodegradable material as an addition to currently used in industrial practice resins are part of a broader, ongoing study concerning the mechanical and thermal behavior of various types of molding and core sands.

\section{Open Access}

This article is distributed under the terms of the Creative Commons Attribution 4.0 International License (http://creativeco mmons.org/licenses/by/4.0/), which permits unrestricted use, distribution, and reproduction in any medium, provided you give appropriate credit to the original author(s) and the source, provide a link to the Creative Commons license, and indicate if changes were made.

\section{References}

1. K. Major-Gabryś, Odlewnicze masy formierskie i rdzeniowe przyjazne dla środowiska (Environmentally Friendly Foundry Moulding and Core Sands), (Archives of Foundry Engineering, Katowice-Gliwice, 2016) ISBN: 978-83-63605-24-7 (in Polish)

2. S.M. Dobosz, P. Jelinek, and K. Major-Gabryś, Development Tendencies of Moulding and Core Sands, China Foundry, 2011, 8(4), p 438446

3. J. Tybulczuk, Forsight Technologiczny Odlewnictwa Polskiego (Technological Forsight of Polish Foundry), (Foundry Research Institute, Krakow, 2009) ISBN: 978-83-88770-42-5 (in Polish)

4. I.A. Bacanu, Nowoczesne technologie Hüttenes-Albertus: Spojrzenie na przyszłość technologii w światowym odlewnictwie (Modern Technologies of Hüttenes-Albertus: A Look at the Future of Technology in Global Foundry), in: 4th Conference Hüttenes-Albertus Poland, on CD-ROM, August 28-30 (Ilawa, Poland, 2014) (in Polish)

5. M. Holtzer, Technologie mas formierskich i rdzeniowych a ochrona środowiska (Technologies of molding and core sands in the aspect of environmental protection), in: 3rd Conference Hüttenes-Albertus Poland, May 20-22 (Zakopane, Poland, 2012), p 19-40 (in Polish)

6. E. Smolik, Wielopierścieniowe weglowodory aromatyczne (WWA) (Polycyclic aromatic hydrocarbons (PAH)), in: Training Materials of the Institute of Occupational Medicine and Environmental Health, "Theory and Practice of Environmental Impact Assessment on Health" (Sosnowiec, Poland, 2001), p 79-86 (in Polish)

7. J.L. Lewandowski, Tworzywa na formy odlewnicze (Materials for Foundry Molds), (WN Akapit, Kraków, 1997), ISBN: 83-7108-21-2 (in Polish)

8. S.M. Dobosz, J.L. Lewandowski, W. Solarski, W. Kilarska, and J. Zawada, Ekologiczna charakterystyka mas formierskich i rdzeniowych (Ecological characteristic of molding and core sand), in: Materials of the 20th Conference of the Foundry Department of AGH and the Metallurgical and Foundry Committee of the Polish Academy of Sciences "Modern Trends in Foundry" (Krakow, Poland, 1995), p 219-224 (in Polish)

9. Y. Wang, F.S. Cannon, D. Neill, K. Crawford, and R.C. Yoight, Effects of Advanced Oxidation Treatment on Green Sand Proprieties and Emissions, AFS Trans., 2014, 112, p 635-648

10. K. Seeger, Zastosowanie pokryć wodnych przy formowaniu recznym (Application of water coverings in manual forming), in: 3rd Conference Hüttenes-Albertus Poland, May 20-22 (Zakopane, Poland, 2012), p 9-18 (in Polish)

11. A. Karwiński, Ekosil- "wodne" spoiwo dla odlewnictwa precyzyjnego (Ekosil— 'Water' Binder for Precision Casting), Bull. Found. Res. Inst., 1999, 5, p 3-15 (in Polish)

12. R. Haratym and A. Karwiński, Wpływ parametrów ekologicznego procesu produkcyjnego na jakość formy ceramicznej i odlewu w 
metodzie wytapianych modeli (Influence of Ecological Parameters of the Production Process on the Quality of the Ceramic Mold and Casting in the Method of Melted Models), Solidif. Met. Alloys, 1999, 14(41), p 106-111 (in Polish)

13. Z. Adamczyk, G. Para, A. Karwiński, and J. Stachańczyk, Influence of surfactant adsorption on properties of ceramic slurries and moulds in investment casting, in 9th World Conference on Investment Casting (San Francisco, California, USA, 1996)

14. A. Serghini, Krzemianowe systemy cold-box-czy moga osiagnać szczyt? (Silicon cold-box systems - can they reach the top?), in 2nd Conference Hüttenes-Albertus Poland, August 29-31, (Kazimierz Dolny, Poland, 2010), p 1-10 (in Polish)

15. P. Groening, Właściwości oraz zastosowanie nowoczesnego systemu cold-box PUR (Properties and application of a modern PUR cold box system), in 4th Conference Hüttenes-Albertus Poland, on CD-ROM, August 28-30 (Iława, Poland, 2014) (in Polish)

16. S.M. Dobosz, Woda w masach formierskich i rdzeniowych (Water in Molding and Core Sands) (WN Akapit, Krakow, 2006) ISBN: $83-$ 89541-62-9 (in Polish)

17. W. Majka, Wpływ parametrów fizykochemicznych na właściwości mas z wybranymi spoiwami dla procesu cold-box (Influence of Physicochemical Parameters on Core Sands Properties with Selected Binders for the Cold-Box Process), Master's diploma dissertation, AGH-University of Science and Technology, Krakow, 2012 (in Polish)

18. N. Benz and C. Fourberg, Przyjazne dla środowiska żywice furanowe z zawartością wolnego alkoholu furfurylowego mniejszą niż $25 \%$ (Environmentally Friendly Furan Resins with a Free Furfuryl Alcohol Content of Less Than 25\%), in: 3rd Conference Hüttenes-Albertus Poland, May 20-22 (Zakopane, Poland, 2012), p 129-137 (in Polish)

19. Hüttenes-Albertus Polska, Katalog Materiałów rdzeniowych, formierskich i pomocniczych dla przemysłu odlewniczego (Catalog of core, molding and auxiliary materials for foundry industry) (in Polish)

20. http://odlew.com.pl/zywice-i-utwardzacze-odlewnicze, 2018. Accessed 10 Feb 2018

21. K. Major-Gabryś, A. Grabarczyk, S.M. Dobosz, and D. Drożyński, Effect of a Biodegradable Addition as a Binary Binder Component for
Casting Moulding and Cores Sands on the Properties of the Binder and the Sands, Trans. Found. Res. Inst., 2016, LVI(4), p 319-328

22. S.M. Dobosz, A. Grabarczyk, and K. Major-Gabryś, Elasticity of Moulding Sands-A Method of Reducing Core Cracking, Arch. Found. Eng., 2017, 17(9), p 31-36

23. B. Hutera, Wpływ temperatury na lepkość wybranego spoiwa odlewniczego (The Effect of Temperature on the Viscosity of the Selected Foundry Binder), Arch. Found. Eng., 2003, 3(9), p 203-208 (in Polish)

24. K. Major-Gabryś, A. Bobrowski, A. Grabarczyk, and S.M. Dobosz, The Thermal and Structural Analysis of New Bicomponent Binders for Moulding Sands Consisting of Furfuryl Resin and Polycaprolactone (PCL), Arch. Metall. Mater., 2017, 62(1), p 369-372

25. G.C. Eastmond, Poly(E-caprolactone) Blends, Adv. Polym. Sci., 2000, 149, p 59-222

26. P. Gröning, S. Schreckenberg, and K. Jenrich, Herstellung von hochkomplexen Zylinderkurbel-gehäusen (Production of Highly Complex Cylinder Crankcases), Part 1, GIESSEREI, 2015, 102(01), p $42-47$ (in German)

27. P. Gröning, S. Schreckenberg, and K. Jenrich, Herstellung von hochkomplexen Zylinderkurbel-gehäusen (Production of Highly Complex Cylinder Crankcases), Part 2, GIESSEREI, 2015, 102(01), p 48-53 (in German)

28. Multiserw-Morek Company device specification (product catalogue). http://multiserw-morek.pl/products, 2014. Accessed 4 Feb 2018

29. A. Grabarczyk and S.M. Dobosz, in 5th Conference of Ph.D. Students at the Faculty of Foundry Engineering, May 9, (AGH University of Science and Technology Krakow, Krakow, 2016)

30. S.M. Dobosz, A. Grabarczyk, and K. Major-Gabryś, Modification of Foundry Binders by Biodegradable Material, Arch. Found. Eng., 2018, 18(2), p 31-34

Publisher's Note Springer Nature remains neutral with regard to jurisdictional claims in published maps and institutional affiliations. 